\section{Epilepsi hos kvinner}

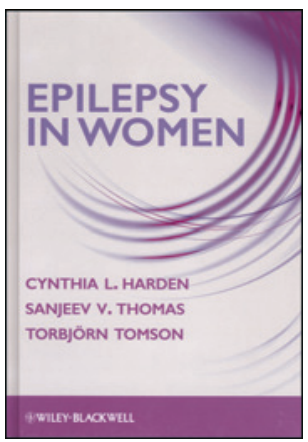

Cynthia L. Harden, Sanjeev V. Thomas,

Torbjörn Tomson, red.

Epilepsy in women

216 s, tab, ill. Chichester: Wiley-Blackwell,

2013. Pris GBP 80

ISBN 978-0-470-67267-9

I denne boken gir 30 forfattere en grei oppsummering av hva vi i dag vet om de viktigste epilepsirelaterte problemene som kan ramme kvinner. De har særlig lagt vekt på katamenial epilepsi (mentruasjons- og ovulasjonsrelaterte anfall), fertilitet, prevensjon, endring av anfallsmønster og farmakokinetikk under svangerskap, utfallet av svangerskapene, risiko for fosterskader ved bruk av forskjellige antiepileptika, amming og menopause.

Er det virkelig behov for en bok bare om kvinner og epilepsi? Personlig tror jeg ikke den vil bli noen bestselger. Til det er fagfeltet for smalt. Dessuten, mange av kapitlene bringer lite nytt. Mest interessant er etter min mening resultater fra flere internasjonale epilepsi- og svangerskapsregistre som de siste årene har gitt oss rimelig gode data på den teratogene risikoen knyttet til de mest brukte antiepileptika (lamotrigin, karbamazepin, valproat). Samtlige registre viser at den største risikoen, ikke bare for morfologiske misdannelser hos barnet, men også for senere nevrokognitive problemer, er knyttet til bruk av valproat. Risikoen viser seg å være doseavhengig - jo høyere dose, desto større risiko. Selv om det er satt frem en del teorier, vet vi fortsatt skuffende lite om mekanismene bak antiepileptikas fosterskadelige effekter.

Hvert kapittel starter og slutter med en kasuistikk som er ment å gi temaet «kjøtt på beinet». Ideen er god, men noen av kasuistikkene er etter mitt skjønn for lange. Dessuten synes jeg det var en sjenerende overlapping av stoff mellom enkelte av kapitlene. Her burde hovedforfatterne foretatt en strammere redigering.

To av kapitlene har norske forfattere, Ingrid Borthen og Nils Erik Gilhus fra Haukeland sykehus har skrevet om obstetriske komplikasjoner, og Erik Taubøll, Line Sveberg Røste og Sigrid Svalheim fra Rikshospitalet har skrevet om katamenial epilepsi.

En liten feil som trolig må tilskrives dårlig korrekturlesing: I siste oppsummerende kulepunkt om behandling av katamenial epilepsi (side 51) er klobazam og acetazolamid, dvs. to farmaka, nevnt under «Nonpharmacologic treatment».

Her i Norge har kollega Line Sveberg Røste tatt et rosverdig initiativ til å lage retningslinjer for behandling av kvinner med epilepsi (1). Mange av kollegene som boken er rettet mot (nevrologer, gynekologer, nevropediatere), vil nok nøye seg med å lese disse retningslinjene. De behandler nemlig mange av de samme temaene.

Jeg tror således dette blir en bok for de spesielt interesserte.

\section{Karl 0. Nakken}

Klinikk for kirurgi og nevrofag

Oslo universitetssykehus, Rikshospitalet

\section{Litteratur}

1. Røste LS, Taubøll E, Gjerstad L et al. Retningslinjer for behandling av kvinner med epilepsi. Konsensusrapport 2011. Oslo: Den norske legeforening, 2011.

\section{Informativt om regionalanestesi}

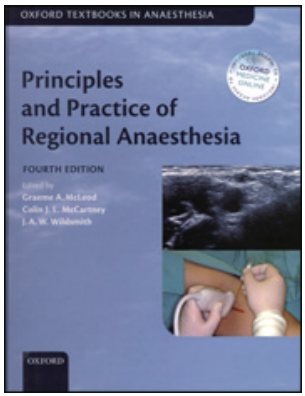

Graeme McLeod, Colin McCartney,

Tony Wildsmith, red.

Principles and practice of regional anaesthesia

4.utg. 277 s, tab, ill. Oxford: Oxford University Press, 2012. Pris GBP 70

ISBN 978-0-19-958669-1

Som tittelen seier, er dette ei lærebok i regionalanestesi. Boka er skreven for fagpersonell som arbeider med regionalanestesi, og den rettar seg spesielt mot legar som er under spesialisering innan anestesi. Forfattarane er hovudsakleg britiske og har sine arbeidsplassar ved ulike sjukehus over heile Storbritannia. Boka har engelsk tekst, men den er lettlesen og har gode figurar.

Første utgåve kom i 1987, og dette er den fjerde utgåva. Mykje har skjedd innan fagfeltet på denne tida, spesielt dei siste åra har bruk av ultralyd vorte vanleg ved regionalanestesi. Denne utgåva har med eit eige kapittel om ultralyd som både beskriv teknologien bak og den praktiske bruken. Dette er informativt utan at det blir for teknisk.

Boka er todelt. Den første delen omfattar generelle prinsipp ved regionalanestesi. Her tar forfattarane for seg fordelar ved regional anestesi og komplikasjonar som kan oppstå. Farmakologi og toksisitet til lokalanestesimiddel blir omtala, og klinisk tilnærming i bruk av regionalanestesi hos pasientar er også med.

I den andre delen tar forfattarane for seg spesifikke metodar innan regionalanestesi. Her gjer dei greie for når det er aktuelt å bruke dei ulike metodane. Anatomi, teknisk utføring og fordelar og ulemper blir forklart. Kvar metode er godt forklart, og fine bilde gjer det heile meir oversiktleg. Det er også her vorte plass til ultralyd med gode og beskrivande ultralydbilde. Regionalanestesi hos overvektige og barn blir tatt opp i eigne kapittel.

Boka vil vere nyttig for legar i spesialisering innan anestesi, den gjev god basiskunnskap og forståing for regionalanestesi. For dei som ønskjer å gå nærare inn på enkelte område, er det fyldige referanselister etter kvart kapittel.

\section{Tore Reikvam}

Haukeland universitetssjukehus 